\title{
OCENA JAKOŚCI ŻYCIA CHORYCH Z OGNISKOWYMI ZMIANAMI NOWOTWOROWYMI W WAৃTROBIE PO TERMOABLACJI PRZEZSKÓRNEJ
}

\author{
EVALUATION OF LIFE QUALITY OF POST PERCUTANEOUS RADIOFREQUENCY \\ THERMALABLATION PATIENTS WITH FOCAL CARCINOMA CHANGES IN LIVER
}

\author{
Beata Dorota Bożek-Bezler, Grażyna Bączyk \\ Zakład Praktyki Pielęgniarskiej, Katedra Pielęgniarstwa \\ Uniwersytet Medyczny im. Karola Marcinkowskiego w Poznaniu
}

DOI: https://doi.org/10.20883/pielpol.2017.49

\begin{abstract}
STRESZCZENIE
Wstęp. Ogniskowe zmiany nowotworowe w obrębie wątroby to najczęstsze powikłanie występujące u pacjentów chorujących na raka jelita grubego. Zalecane przez specjalistów regularne badania USG oraz KT gruczołu stanowią szansę na wcześniejsze wykrycie zmian i wprowadzenie odpowiedniego leczenia. Głównymi standardowymi metodami terapeutycznymi są chemioterapia oraz klasyczny zabieg laparotomii na jamie brzusznej. Radykalne i rozległe leczenie operacyjne niesie ze sobą wiele bólu, stresu oraz wydłuża czas rekonwalescencji chorego. Najnowsza dostępna metoda, jaką jest termoablacja przezskórna, stanowi alternatywę poprzedzającą rozległą terapię.

Cel. Głównym celem badań była ocena jakości życia chorych z ogniskowymi zmianami nowotworowymi w wątrobie przed termoablacją przezskórną wątroby i po wykonaniu tego zabiegu.

Materiał i metody. W celu potwierdzenia słuszności i pozytywnego wpływu zabiegu termoablacji na jakość życia i stan zdrowia przeprowadzono badania na 31 chorych. Pacjenci zarówno przed zabiegiem, jak i 2 tygodnie po zabiegu zostali przebadani za pomocą kwestionariusza WHOQOL-BREF oraz EORTC-QLQ C30. Według obu zastosowanych narzędzi badawczych jakość życia chorych uległa znacznej poprawie mimo krótkiego czasu, jaki minął po przeprowadzonej ablacji.

Wnioski. Metoda termoablacji przezskórnej stanowi nową, mniej inwazyjną alternatywę leczenia dla pacjentów zmagających się ze zmianami nowotworowymi w obrębie wątroby. Przedstawione w pracy badania należałoby poszerzyć o dodatkowe zmienne, które bardziej dokładnie umożliwią zapoznanie się z zagadnieniem jakości życia i pozytywnych rezultatów zastosowanej metody leczenia.
\end{abstract}

SŁOWA KLUCZOWE: nowotworowe zmiany ogniskowe w wątrobie, termoablacja przezskórna wątroby, jakość życia, nowotwór jelita grubego, termoablacja.

\section{Wstęp}

Ogniskowe zmiany nowotworowe w obrębie wątroby stanowią najczęstsze dalsze powikłania u chorych zmaga-

\begin{abstract}
Introduction. Focal carcinoma changes within liver are the most common complication considering patients with large intestine cancer. According to experts' recommendations, regular USG and CT examinations are a chance for the early detection and application of proper treatment. Basic treatment methods are chemotherapy and conventional abdomen laparotomy. Radical and extensive surgical treatment is painful, stressful and significantly extends convalescence. The alternative treatment preceding extensive therapy is the newest radiofrequency thermal ablation method.

Aim. The main objective of the research was to assess life quality of patients with focal tumor lesions in the liver before and after treatment of percutaneous radiofrequency ablation of the liver.

Material and methods. The study on 31 patients was carried to prove validity and positive influence on life quality and health after radiofrequency thermal ablation. Patients were tested two weeks before and after treatment using WHOQOL-BREF and EORTCQLQ C30 questionnaires. Despite the short period of time after ablation, patients' health quality considerably improved according to both used testing tools.

Conclusions. Percutaneous radiofrequency thermal ablation is a less invasive alternative for patients affected with carcinoma changes within the liver. Tests presented in this paper ought to be completed with additional variables which will provide precise information about the life quality issue and positive results of applied treatment.
\end{abstract}

KEYWORDS: focal carcinoma changes in the liver, percutaneous radiofrequency thermal ablation of the liver, life quality, large intestine carcinoma, radiofrequency thermalablation.

jących się z nowotworem jelita grubego, u osób palących papierosy, nadużywających alkoholu, a także u młodych kobiet stosujących doustne środki antykoncepcyjne [1]. 
Trudność w leczeniu zmian opiera się głównie na zbyt późnym wykryciu ognisk nowotworowych, gdyż nie dają żadnych konkretnych objawów mogących niepokoić chorego. Według zaleceń ASCO (American Society of Clinical Oncology) możliwe jest wcześniejsze udzielenie pomocy i wdrożenie odpowiedniego leczenia dzięki badaniom kontrolnym, takim jak tomografia komputerowa jamy brzusznej czy badania laboratoryjne [2, 3].

Leczenie przerzutów do wątroby, jakimi są zmiany ogniskowe, opiera się na metodzie inwazyjnej, czyli tradycyjnym zabiegu operacyjnym, metodzie farmakologicznej, nie do końca dającej zadowalające efekty, lub najnowszej metodzie nieinwazyjnej, jaką jest zabieg termoablacji przezskórnej wątroby [4]. Ta stosunkowo młoda i perspektywiczna metoda leczenia stanowi ogromny postęp w kierunku zmniejszenia powikłań pooperacyjnych oraz lepszym rokowaniu pacjenta. Stan fizyczny oraz psychiczny, a w szczególności jakość życia chorego ulegają znacznej poprawie, dając szansę na dłuższe życie [5, 6].

Rozpoczynając terapię, wielu pacjentów obawia się ponownych powikłań, bólu oraz rekonwalescencji związanych z rozległym zabiegiem operacyjnym. Jakość ich życia oraz zdrowie psychiczne ponownie ulegają pogorszeniu [7, 8].

Jednakże dzięki najnowszej metodzie leczenia, jaką jest termoablacja przezskórna wątroby, chorzy mają szansę uniknąć większości swoich obaw. Terapia ta ma za zadanie jak najmniej inwazyjnie, a najbardziej, jak to możliwe, wyleczyć pacjenta, zachowując przy tym jak najlepszą jakość jego życia $[9,10]$.

Konkretnych prac badawczych w kierunku jakości życia chorych z ogniskowymi zmianami w obrębie wątroby nie ma. Oceny po leczeniu metodą termoablacji przezskórnej także brak. Podjęcie tego tematu jest ważne oraz potrzebne, gdyż pomoże to zrozumieć problemy, z jakimi borykają się pacjenci oraz z czym wiąże się dokładność zastosowanego leczenia w sferze zarówno somatycznej, jak i psychicznej.

Niniejszą pracę uznać można za pionierską w dziedzinie badań jakościowych, medycyny oraz pielęgniarstwa odnośnie poruszanego tematu. Zaznaczyć należy, że stanowi ona początek dalszych oraz szerszych badań w tym zakresie.

\section{Cel pracy}

Głównym celem badań była ocena jakości życia chorych z ogniskowymi zmianami nowotworowymi w wątrobie przed termoablacją przezskórną wątroby i po wykonaniu tego zabiegu.

Problemy badawcze:

- Jak oceniana jest jakość życia pacjentów przed termoablacją przeskórną wątroby i po wykonaniu tego zabiegu?
- Jaka jest jakość życia pacjentów (z uwzględnieniem płci i wieku) przed termoablacją przeskórną wątroby?

- Jaka jest jakość życia pacjentów (z uwzględnieniem płci i wieku) po termoablacji przeskórnej wątroby?

\section{Materiał i metody}

W przeprowadzonych badaniach technikę badawczą stanowiła metoda sondażu diagnostycznego w postaci kwestionariusza i ankiet, które poprzedzone zostały wstępem zawierającym informację na temat celu, zasad oraz rodzaju badania, którym zostali poddani wyrażający na to zgodę pacjenci. Kwestionariusz osobowy składał się z 9 pytań otwartych i zamkniętych, w których możliwe było uzyskanie podstawowych danych (zmiennych) na temat badanego pacjenta, np. płeć, wiek, wykształcenie czy jednostka chorobowa. Został on stworzony samodzielnie zgodnie z zasadami tworzenia metryczek informacyjnych [11].

Do badań wykorzystano również specyficzną skalę EORTC QLQ-C30 w wersji 3.0 w języku polskim oraz skróconą polską wersję WHOQOL-BREF.

Kwestionariusz EORTCQLQ-C30 (ang. European Organization for Research and Treatment of Cancer Quality of Life Questionnaire - Core 30) skonstruowała Grupa Badawcza Jakości Życia, powołana przez Europejską Organizację Badań i Leczenia Nowotworów (EORTC). EORTC QLQ-C30 to część modułowego i wszechstronnego podejścia do pomiaru jakości życia pacjentów z chorobą nowotworową bez uwzględnienia rodzaju czy lokalizacji choroby [11]. W kwestionariuszu podstawowym umieszczono 30 pytań, które dotyczą wpływu choroby na funkcjonowanie w różnych obszarach życia oraz wpływu dolegliwości na jakość życia chorego. Funkcjonowanie pacjentów mierzone jest poprzez skale takie jak: funkcjonowanie: fizyczne (w rolach społecznych i w pracy), emocjonalne, poznawcze, społeczne oraz ogólna jakość życia. Skale, które skupiają się na ocenie wpływu objawów na jakość życia, obejmują: zmęczenie, nudności i wymioty, ból, duszność, zaburzenia snu, utratę apetytu, zaparcie stolca i biegunkę. Dodatkowo uwzględnia się także wpływ choroby na sytuację finansową chorego. W zadawanych pytaniach kwestionariusza EORTC QLQ-C30 zastosowano 4-stopniową skalę Likerta, z wyjątkiem tych dotyczących oceny stanu zdrowia i ogólnej jakości życia pacjenta, gdzie posłużono się skalą 7-stopniową [11-14].

Skala WHOQOL-BREF także ocenia jakość życia chorego, opierając się na czterech obszarach życia, takich jak: fizyczny, psychologiczny, społeczny oraz środowiskowy. Zastosowana w badaniach skala jest wersją skróconą i składa się z 26 pytań. Punktacja mieści się w przedziale od 1 (bardzo zła) do 5 (bardzo dobra). 
Im większa liczba zebranych punktów, tym oceniana jakość życia jest lepsza. Zapytanie numer jeden oraz dwa ankiety analizowane są oddzielnie. Pierwsze odnosi się do indywidualnej oraz ogólnej jakości życia, natomiast drugie do indywidualnego postrzegania własnego zdrowia [12, 13].

Przeprowadzone badania rozpoczęto w marcu 2015 roku, a zakończono w czerwcu 2015 roku. Niewielka grupa badanych (31 chorych) świadczy o tym, że nie wszyscy przyjęci do szpitala pacjenci zostali zakwalifikowani do dalszego leczenia (niespełnione warunki kategoryzacji do zabiegu, stawianych przez ośrodek), jaką jest metoda termoablacji przezskórnej, oraz nie wszyscy wyrazili zgodę na udział w badaniu ankietowym. Obserwacja pacjentów prowadzona była na terenie Szpitala Miejskiego im. Franciszka Raszei w Poznaniu na Oddziale Chirurgii Ogólnej, Minimalnie Inwazyjnej i Urazowej, wśród mężczyzn i kobiet.

\section{Analiza statystyczna}

Dla zmiennych na skalach jakościowych wyniki przedstawiono za pomocą liczebności (n) oraz wskaźnika struktury (\%). Dla zmiennych na skalach ilościowych wyliczono średnią arytmetyczną (M), medianę (Me), kwartyle (Q1 i Q3), wartości minimalne i maksymalne oraz odchylenie standardowe (SD). Zgodność rozkładu poszczególnych skal z rozkładem normalnym badano przy użyciu testu Shapiro-Wilka. Ponieważ zmienne nie spełniały założenia o normalności rozkładu, hipotezy weryfikowano za pomocą testów nieparametrycznych: testu kolejności par Wilcoxona, testu U Manna-Whitneya oraz współczynnika korelacji rang Spearmana. Założono poziom istotności $\alpha=0,05$. Za istotne statystycznie uznawano wyniki, gdy wyliczone prawdopodobieństwo testowe $p$ spełniało nierówność $p<0,05$. Do analizy statystycznej wykorzystany został program Statistica 10.0 (StatSoft Inc., 2011).

\section{Wyniki}

Badania przeprowadzono na grupie 31 chorych, u których w wyniku poszczególnych jednostek chorobowych doszło do wystąpienia przerzutów w obrębie narządu wątroby określanych jako nowotworowe zmiany ogniskowe. W pełnym rozkładzie badanej grupy 54,8\% stanowiły kobiety, a $45,2 \%$ to mężczyźni (Tabela 1). Przedstawiane poniżej dane odnoszą się do informacji zawartych w metryczce poprzedzającej zastosowane do badań ankiety. Uwzględniają: wiek badanych, ich wykształcenie, miejsce zamieszkania, status zawodowy, stan cywilny, główne rozpoznanie jednostki chorobowej, zastosowane leczenie oraz czas, jaki minął od wykonanego zabiegu operacyjnego. Informacje te sta- nowią podstawowe źródło wiedzy na temat chorego, dzięki czemu analiza danego przypadku w kontekście oceny jakości życia pacjenta jest bardziej przejrzysta i możliwa do porównania odnośnie podobieństw czy różnic między jednym a drugim chorym. Mogą stanowić również potwierdzenie, iż te aspekty mają pewien wpływ na przebieg choroby, leczenia czy jakość zdrowia. Grupa badanych została podzielona na trzy kategorie ze względu na wiek: pierwsza w przedziale od 26 do 45 lat, druga - od 46 do 60 lat, trzecia - powyżej 60 lat. Rozkład wykształcenia badanych osób podzielono na cztery kategorie: podstawowe, zawodowe, średnie oraz wyższe. Kolejny rozkład procentowy przedstawia status zawodowy badanych pacjentów. Niezwykle istotną informacją jest podstawowe rozpoznanie jednostki chorobowej; badani wymienili: nowotwór jelita grubego (najliczniejsza grupa chorobowa), nowotwór wątroby, nowotwór piersi, nowotwór odbytu, guz ogona trzustki oraz nowotwór żołądka. Pacjenci zapytani o rodzaj zastosowanego leczenia wskazali: w najwyższym procencie chemioterapię oraz metody operacyjne, następnie radioterapię oraz leczenie farmakologiczne (określone jako bardziej rozszerzone/ inne niż podstawowe wg pacjenta). W odniesieniu do upływu czasu od leczenia operacyjnego ankietowani w największym procencie wskazali przedział od roku do 2 lat od wykonanego zabiegu, następnie do roku od operacji oraz powyżej 2 lat od zabiegu.

Tabela 1. Charakterystyka społeczno-demograficzna i kliniczna badanych Table 1. Socio-demographic and clinical characteristics of the respondents

\begin{tabular}{|c|c|c|}
\hline \multicolumn{3}{|c|}{$\begin{array}{c}\text { Rozkład procentowy badanej grupy z uwzględnieniem podziału na płeć/ } \\
\text { Percentage distribution of the study group, taking into account sex } \\
\text { categories }\end{array}$} \\
\hline $\begin{array}{l}\text { Płeć/ } \\
\text { Gender }\end{array}$ & Liczba/ & Procent/ \\
\hline kobieta/woman & 17 & 54,8 \\
\hline mężczyzna/man & 14 & 45,2 \\
\hline \multicolumn{3}{|c|}{$\begin{array}{c}\text { Rozkład procentowy badanej grupy z uwzględnieniem podziału na } \\
\text { kategorie wiekowe/Percentage distribution of the study group, taking into } \\
\text { account age categories }\end{array}$} \\
\hline $\begin{array}{l}\text { Wiek/ } \\
\text { Age }\end{array}$ & $\begin{array}{l}\text { Liczba/ } \\
\text { Number }\end{array}$ & $\begin{array}{c}\text { Procent/ } \\
\text { Percentage }\end{array}$ \\
\hline 26-45 lat/years & 3 & 9,7 \\
\hline 46-60 lat/years & 9 & 29,0 \\
\hline powyżej 60 lat/over 60 years & 19 & 61,3 \\
\hline \multicolumn{3}{|c|}{$\begin{array}{l}\text { Rozkład procentowy badanej grupy z uwzględnieniem podziału na } \\
\text { wykształcenie/Percentage distribution of the study group, taking into to } \\
\text { account education }\end{array}$} \\
\hline $\begin{array}{c}\text { Wykształcenie/ } \\
\text { Education }\end{array}$ & $\begin{array}{l}\text { Liczba/ } \\
\text { Number }\end{array}$ & $\begin{array}{l}\text { Procent/ } \\
\text { Percentage }\end{array}$ \\
\hline podstawowe/primary education & 3 & 9,7 \\
\hline zawodowe/basic vocational education & 10 & 32,3 \\
\hline średnie/secondary education & 10 & 32,3 \\
\hline wyższe/higher education & 8 & 25,8 \\
\hline
\end{tabular}


Rozkład procentowy badanej grupy z podziałem na miejsce zamieszkania/Percentage distribution of the study group, taking into to account the place of residence

\begin{tabular}{|c|c|c|}
\hline $\begin{array}{l}\text { Miejsce zamieszkania/ } \\
\text { Place of residence } \\
\text { wieś/village }\end{array}$ & $\begin{array}{l}\text { Liczba/ } \\
\text { Number } \\
3\end{array}$ & $\begin{array}{c}\text { Procent/ } \\
\text { Percentage } \\
9,7\end{array}$ \\
\hline $\begin{array}{l}\text { miasto do } 25 \text { tys. mieszkańców/city up } \\
\text { to } 25 \text { thousands of residents }\end{array}$ & 7 & 22,6 \\
\hline $\begin{array}{l}\text { miasto 25-100 tys. mieszkańców/city } \\
25-100 \text { thousands of residents }\end{array}$ & 11 & 35,5 \\
\hline $\begin{array}{l}\text { miasto powyżej } 100 \text { tys. mieszkańców/ } \\
\text { city more than } 100 \text { thousands of re- } \\
\text { sidents }\end{array}$ & 10 & 32,3 \\
\hline
\end{tabular}

Rozkład procentowy badanej grupy z podziałem na status zawodowy/ Percentage distribution of the study group, taking into to account the professional status

$\begin{array}{ccc}\text { Praca zawodowa/ } & \text { Liczba/ } & \text { Procent/ } \\ \text { Professional work } & \text { Number } & \text { Percentage } \\ \text { pracująca/y/working } & 7 & 22,6 \\ \text { emeryt/rencista/pensioner } & 20 & 64,5 \\ \text { racuję/bez pracy/unemployed } & 4 & 12,9\end{array}$

Rozkład procentowy badanej grupy z podziałem na stan cywilny/ Percentage distribution of the study group, taking into to account the marital status

$\begin{array}{ccc}\text { Stan cywilny/ } & \text { Liczba/ } & \text { Procent/ } \\ \text { Marital status } & \text { Number } & \text { Percentage } \\ \text { samotna/y/single } & 2 & 6,5 \\ \text { zamężna/żonaty/married } & 19 & 61,3 \\ \text { wolny związek/free relation } & 3 & 9,7 \\ \text { wdowa/wdowiec/widow/er } & 7 & 22,6\end{array}$

Rozkład procentowy badanej grupy z podziałem na rozpoznanie podstawowej jednostki chorobowej/

Percentage distribution of the study group, taking into to account primary disease

Rozpoznanie/
Disease

\begin{tabular}{|c|c|}
\hline $\begin{array}{l}\text { Liczba/ } \\
\text { Number }\end{array}$ & $\begin{array}{c}\text { Procent/ } \\
\text { Percentage }\end{array}$ \\
\hline 14 & 45,2 \\
\hline 11 & 35,5 \\
\hline 3 & 9,7 \\
\hline 1 & 3,2 \\
\hline 1 & 3,2 \\
\hline 1 & 3,2 \\
\hline
\end{tabular}

nowkład procentowy zastosowanego leczenia/Percentage distribution of the study group, taking into to account the treatment Leczenie/ Liczba/ Procent/ Treatment Number Percentage

$\begin{array}{lll}\text { operacyjne/surgery } & 28 & 90,3\end{array}$

radioterapia/radiotherapy $\quad 9 \quad 29,0$

chemioterapia/chemotherapy $\quad 28 \quad 90,3$

$\begin{array}{lll}\text { farmakologiczne/pharmacological } & 1 & 3,2\end{array}$

Czas, jaki minął od wykonania zabiegu operacyjnego/ Time passed since surgery

\begin{tabular}{ccc} 
Czas od operacji/ & Liczba/ & Procent/ \\
Time passed since surgery & Number & Percentage \\
do 1 roku/up to 1 year & 9 & 29,0 \\
1-2 lata/years & 13 & 41,9 \\
powyżej 2 lat/over 2 years & 6 & 19,4 \\
bez operacj//no operation & 3 & 9,7 \\
RAZEM/TOTAL & 31 & 100,0 \\
\hline
\end{tabular}

Źródło: badania własne

Source: author's own materials
Do oceny jakości życia badanych pacjentów zarówno przed termoablacją przezskórną wątroby, jak i po wykonaniu tego zabiegu posłużono się kwestionariuszami EORTC QLQ-C30 wersja 3.0 oraz WHOQOL BREF.

W przyjętym narzędziu badawczym EORTC QLQ-C30 skale oceniające jakość życia chorego dzielą się na funkcjonalne oraz objawowe. Przy pomiarze w skali funkcjonalnej za najlepszy wynik przyjmuje się 100; im wyższy wynik, tym lepsze funkcjonowanie. Przy pomiarze w skali objawowej za najlepszy wynik przyjmuje się 0 .

Tabela 2. Wyniki pierwszego pomiaru (EORTC QLQ-C30) Table 2. Results of the first measurement (EORTC QLQ-C30)

\begin{tabular}{cccccccc}
\hline $\begin{array}{c}\text { Skale funkcjonalne/ } \\
\text { Functional scales }\end{array}$ & $\mathrm{M} \pm \mathrm{SD}$ & $\mathrm{Me}$ & Min. & Maks. & $\mathrm{Q} 1$ & $\mathrm{Q} 3$ \\
\hline $\begin{array}{c}\text { Stan zdrowia i jakośc życia/ } \\
\text { Health and quality of life }\end{array}$ & $46,2 \pm 19,2$ & 41,7 & 16,7 & 91,7 & 33,3 & 58,3 \\
$\quad \begin{array}{c}\text { Funkcje fizyczne/ } \\
\text { Physical functions }\end{array}$ & $74,8 \pm 17,1$ & 73,3 & 40,0 & 100,0 & 66,7 & 86,7 \\
\hline $\begin{array}{c}\text { Pełnienie swej roli/ } \\
\text { Playing one's role }\end{array}$ & $74,2 \pm 19,6$ & 66,7 & 33,3 & 100,0 & 66,7 & 100,0 \\
$\begin{array}{c}\text { Funkcje emocjonalne/ } \\
\text { Emotional functions }\end{array}$ & $49,5 \pm 25,9$ & 50,0 & 0,0 & 100,0 & 33,3 & 75,0 \\
\hline $\begin{array}{c}\text { Funkcje poznawcze/ } \\
\text { Cognition functions }\end{array}$ & $77,4 \pm 19,0$ & 66,7 & 33,3 & 100,0 & 66,7 & 100,0 \\
\hline $\begin{array}{c}\text { Funkcje społeczne/ } \\
\text { Social functions }\end{array}$ & $65,1 \pm 26,3$ & 66,7 & 0,0 & 100,0 & 50,0 & 83,3 \\
\hline
\end{tabular}

Q1 - dolny kwartyl/lower quartile; Q3 - górny kwartyl/the upper quartile; Me - mediana/median; M - średnia arytmetyczna/arithmetic average; SD - odchylenie standardowe/standard deviation; Min. - wartość minimalna/minimum value; Maks. - wartość maksymalna/maximum value

Źródło: badania własne

Source: author's own materials

Tabela 3. Wyniki drugiego pomiaru (EORTC QLQ-C30)/(2 tygodnie po zabiegu)

Table 3. Results of the second measurement (EORTC QLQ-C30)/(2 weeks after operation)

\begin{tabular}{|c|c|c|c|c|c|c|}
\hline $\begin{array}{l}\text { Skale funkcjonalne/ } \\
\text { Functional scales }\end{array}$ & $\mathrm{M} \pm \mathrm{SD}$ & $\mathrm{Me}$ & Min. & Maks. & Q1 & Q3 \\
\hline $\begin{array}{c}\text { Stan zdrowia i jakość życia/ } \\
\text { Health and quality of life }\end{array}$ & $55,6 \pm 17,8$ & 58,3 & 16,7 & 91,7 & 50,0 & 66,7 \\
\hline $\begin{array}{l}\text { Funkcje fizyczne/ } \\
\text { Physical functions }\end{array}$ & $77,6 \pm 16,0$ & 80,0 & 46,7 & 100,0 & 66,7 & 93,3 \\
\hline $\begin{array}{l}\text { Pełnienie swej roli/ } \\
\text { Playing one's role }\end{array}$ & $75,8 \pm 20,1$ & 66,7 & 33,3 & 100,0 & 66,7 & 100,0 \\
\hline $\begin{array}{l}\text { Funkcje emocjonalne/ } \\
\text { Emotional functions }\end{array}$ & $75,3 \pm 14,0$ & 83,3 & 41,7 & 100,0 & 66,7 & 83,3 \\
\hline $\begin{array}{l}\text { Funkcje poznawcze/ } \\
\text { Cognitive functions }\end{array}$ & $79,0 \pm 21,5$ & 83,3 & 33,3 & 100,0 & 66,7 & 100,0 \\
\hline $\begin{array}{l}\text { Funkcje społeczne/ } \\
\text { Social functions }\end{array}$ & $66,1 \pm 24,1$ & 66,7 & 16,7 & 100,0 & 50,0 & 83,3 \\
\hline
\end{tabular}

Źródło: badania własne

Source: author's own materials 
Tabela 4. Porównanie funkcjonowania chorych przed zabiegiem termoablacji przezskórnej wątroby i po zabiegu termoablacji (wyniki testu Wilcoxona)

Table 4. Comparing the functioning of patients before liver thermal radiofrequency ablation surgery and after surgery (Wilcoxon test results)

\begin{tabular}{ccc}
\hline Podskala/Subscale & $\mathrm{Z}$ & $\mathrm{p}$ \\
\hline Stan zdrowia i jakość życia/Health and quality of life & 4,4 & $\mathbf{0 , 0 0 0 0}$ \\
\hline Funkcje fizyczne/Physical functions & 2,9 & 0,0033 \\
\hline Pełnienie swej roli/Playing one's role & 1,6 & 0,1088 \\
\hline Funkcje emocjonalne/Emotional functions & 4,5 & $\mathbf{0 , 0 0 0 0}$ \\
\hline Funkcje poznawcze/Cognition functions & 0,4 & 0,7150 \\
\hline Funkcje społeczne/Social functions & 0,8 & 0,4227 \\
\hline
\end{tabular}

Z - wartość statystyki testu Wilcoxona/Wilcoxon test statistic value; p-poziom istotności/level of significance

Źródło: badania własne

Source: author's own materials

Analiza wykazała, iż w odniesieniu do każdej z podskal funkcjonalnych średnie wartości przy pomiarze drugim były większe niż w pomiarze pierwszym. Największe różnice dotyczyły funkcji emocjonalnych: wzrost średniej z 49,5 w pierwszym pomiarze do 75,3 w drugim pomiarze, różnica istotna statystycznie $(p<$ 0,0001). Wyraźnie polepszyła się również ocena stanu zdrowia i jakości życia: wzrost średniej z 46,2 do wartości 55,6, różnica istotna statystycznie ( $p<0,0001)$. Nieco mniejsza poprawa, ale również istotna statystycznie ( $p=0,0033$ ), dotyczyła funkcji fizycznych (wzrost $z$ średniej 74,8 do 77,6$)$. Pozostałe pomiary nie są istotne statystycznie (Tabela 4).

Tabela 5. Nasilenie występowania objawów u chorych przed zabiegiem termoablacji przezskórnej wątroby (EORTC QLQ-C30) Table 5. The severity of symptoms in patients before thermal radiofrequency ablation of the liver (EORTC QLQ-C30)

\begin{tabular}{ccccccc}
\hline $\begin{array}{c}\text { Skale objawowe/ } \\
\text { Symptomatic scales }\end{array}$ & $\mathrm{M} \pm \mathrm{SD}$ & $\mathrm{Me}$ & Min. & Maks. & $\mathrm{Q} 1$ & $\mathrm{Q} 3$ \\
\hline $\begin{array}{c}\text { Zmęczenie/ } \\
\text { Fatigue }\end{array}$ & $41,6 \pm 17,4$ & 44,4 & 11,1 & 66,7 & 33,3 & 55,6 \\
$\begin{array}{c}\text { Nudności/wymioty/ } \\
\text { Nausea/vomiting }\end{array}$ & $10,2 \pm 17,6$ & 0,0 & 0,0 & 66,7 & 0,0 & 16,7 \\
$\begin{array}{c}\text { Bóle/ } \\
\text { Headaches }\end{array}$ & $25,8 \pm 23,1$ & 33,3 & 0,0 & 83,3 & 0,0 & 33,3 \\
$\begin{array}{c}\text { Duszności/ } \\
\text { Shortness of breath } \\
\text { Bezsenność/ } \\
\text { Insomnia }\end{array}$ & $11,8 \pm 18,4$ & 0,0 & 0,0 & 66,7 & 0,0 & 33,3 \\
$\begin{array}{c}\text { Brak apetytu/ } \\
\text { Lack of apetite } \\
\text { Zaparcia/ }\end{array}$ & $22,6 \pm 23,4$ & 33,3 & 0,0 & 66,7 & 0,0 & 33,3 \\
$\begin{array}{c}\text { Constipation } \\
\text { Biegunka/ } \\
\text { Diarrhoea }\end{array}$ & $15,1 \pm 22,5$ & 0,0 & 0,0 & 66,7 & 0,0 & 33,3 \\
\hline $\begin{array}{c}\text { Problemy finansowe/ } \\
\text { Financial problems }\end{array}$ & $8,6 \pm 17,1$ & 0,0 & 0,0 & 66,7 & 0,0 & 0,0 \\
\hline
\end{tabular}

Źródło: badania własne

Source: author's own materials
Tabela 6. Nasilenie występowania objawów u chorych po zabiegu termoablacji przezskórnej wątroby (EORTC QLQ-C30)/2 tygodnie po zabiegu

Table 6. The severity of symptoms in patients after thermal radiofrequency ablation of the liver (EORTC QLQ-C30)/2 weeks after operation

\begin{tabular}{|c|c|c|c|c|c|c|}
\hline $\begin{array}{c}\text { Skale objawowe/ } \\
\text { Symtomatic scales }\end{array}$ & $\mathrm{M} \pm \mathrm{SD}$ & $\mathrm{Me}$ & Min. & Maks. & Q1 & Q3 \\
\hline Zmęczenie/Fatigue & $32,3 \pm 12,0$ & 33,3 & 11,1 & 66,7 & 22,2 & 33,3 \\
\hline $\begin{array}{l}\text { Nudności/wymioty/ } \\
\text { Nausea/vomiting }\end{array}$ & $5,4 \pm 10,0$ & 0,0 & 0,0 & 33,3 & 0,0 & 16,7 \\
\hline Bóle/Headaches & $22,0 \pm 16,3$ & 33,3 & 0,0 & 50,0 & 0,0 & 33,3 \\
\hline Duszności/Shortness of breath & $9,7 \pm 17,6$ & 0,0 & 0,0 & 66,7 & 0,0 & 33,3 \\
\hline Bezsenność/Insomnia & $35,5 \pm 24,2$ & 33,3 & 0,0 & 66,7 & 33,3 & 66,7 \\
\hline Brak apetytu/Lack of apetite & $11,8 \pm 16,2$ & 0,0 & 0,0 & 33,3 & 0,0 & 33,3 \\
\hline Zaparcia/Constipation & $17,2 \pm 20,9$ & 0,0 & 0,0 & 66,7 & 0,0 & 33,3 \\
\hline Biegunka/Diarrhoea & $6,5 \pm 13,4$ & 0,0 & 0,0 & 33,3 & 0,0 & 0,0 \\
\hline $\begin{array}{l}\text { Problemy finansowe/ } \\
\text { Financial problems }\end{array}$ & $41,9 \pm 27,2$ & 33,3 & 0,0 & 100,0 & 33,3 & 66,7 \\
\hline
\end{tabular}

Źródło: badania własne

Source: author's own materials

Tabela 7. Porównanie funkcjonowania chorych przed zabiegiem termoablacji przezskórnej wątroby i po zabiegu termoablacji (wyniki testu Wilcoxona)

Table 7. Comparing the functioning of patients before liver thermal radiofrequency ablation surgery and after surgery (Wilcoxon test results)

\begin{tabular}{ccc}
\hline Objawy/Symptoms & Z & p \\
\hline Zmęczenie/Fatigue & 3,3 & $\mathbf{0 , 0 0 0 8}$ \\
\hline Nudności/wymioty/Nausea/vomiting & 1,7 & 0,0926 \\
Bóle/Headaches & 1,2 & 0,2220 \\
Duszności/Shortness of breath & 1,3 & 0,1797 \\
Bezsenność/Insomnia & 2,8 & $\mathbf{0 , 0 0 5 1}$ \\
Brak apetytu/Lack of apetite & 2,6 & $\mathbf{0 , 0 0 9 9}$ \\
Zaparcia/Constipation & 0,4 & 0,7150 \\
Biegunka/Diarrhoea & 1,1 & 0,2733 \\
Problemy finansowe/Financial problems & 0,0 & 1,0000 \\
\hline
\end{tabular}

Źródło: badania własne

Source:author's own materials

Za wyjątkiem problemów fizycznych i zaparć objawy uległy zmniejszeniu. Wyniki istotne statystycznie dotyczyły zmęczenia ( $p=0,0008)$, bezsenności $(p=0,0051)$ oraz braku apetytu ( $p=0,0099)$ (Tabela 7$)$.

Uzyskane wyniki pomiaru z zastosowanego narzędzia badawczego WHOQOL-BREF:

Tabela 8. Porównanie funkcjonowania chorych przed zabiegiem termoablacji przezskórnej wątroby i po zabiegu termoablacji (wyniki testu Wilcoxona)

Table 8. Comparing the functioning of patients before liver thermal radiofrequency ablation surgery and after surgery (Wilcoxon test results)

\begin{tabular}{ccc}
\hline Dziedzina/Discipline & $\mathrm{Z}$ & $\mathrm{p}$ \\
\hline Dziedzina fizyczna/Physical discipline & 3,8 & $\mathbf{0 , 0 0 0 2}$ \\
Dziedzina psychologiczna/Psychological discipline & 4,6 & $\mathbf{0 , 0 0 0 0}$ \\
Relacje społeczne/Social relations & 0,5 & 0,5930 \\
Srodowisko/Environment & 1,9 & 0,0630 \\
\hline
\end{tabular}

Z - wartość statystyki testu Wilcoxona/Wilcoxon test statistic value; $\mathrm{p}$ - poziom istotności/level of significance

Źródło: badania własne

Source: author's own materials 
Nieznaczna, ale istotna statystycznie poprawa dotyczyła dziedzin fizycznej $(p=0,0002)$ i psychologicznej $(p<0,0001)$.

Dokonano również pomiaru porównującego jakość życia u kobiet i mężczyzn, stosując test U Manna-Whitneya. Wszystkie wyniki w obu grupach są nieistotne statystycznie, co oznacza, że nie wystąpiły różnice w jakości życia zarówno u kobiet, jak i u mężczyzn.

Przy użyciu współczynnika korelacji rang Spearmana wykonano również analizę porównawczą wieku badanych osób z wynikami uzyskanymi na poszczególnych skalach. Stwierdzono brak jakiejkolwiek korelacji w przyjętej zmiennej wieku a poszczególnymi zmiennymi ze skal.

Tabela 9. Wyniki korelacji pomiaru pierwszego (I) i drugiego (II) z zastosowaniem testu Spearmana

Table 9. The correlation results of the first (I) and second (II) measurement using the Spearman test

\begin{tabular}{|c|c|c|}
\hline Para zmiennych/Pair of variables & R Spearman & $\mathrm{p}$ \\
\hline $\begin{array}{l}\text { Wiek (lata) vs (I) stan zdrowia i jakość życia/ } \\
\text { Age(years)vs(I)health and quality of life }\end{array}$ & $-0,06$ & 0,7348 \\
\hline $\begin{array}{l}\text { Wiek (lata) vs (II) stan zdrowia i jakość życia/ } \\
\text { Age(years)vs(II)health and quality of life }\end{array}$ & 0,04 & 0,8304 \\
\hline $\begin{array}{l}\text { Wiek (lata) vs (I) funkcje fizyczne/ } \\
\text { Age(years)vs(I) physical functions }\end{array}$ & $-0,28$ & 0,1209 \\
\hline $\begin{array}{l}\text { Wiek (lata) vs (II) funkcje fizyczne/ } \\
\text { Age(years)vs(II) physical functions }\end{array}$ & $-0,32$ & 0,0761 \\
\hline $\begin{array}{l}\text { Wiek (lata) vs (I) pełnienie swej roli/ } \\
\text { Age(years)vs(I) playing one's role }\end{array}$ & $-0,03$ & 0,8932 \\
\hline $\begin{array}{l}\text { Wiek (lata) vs (II) pełnienie swej roli/ } \\
\text { Age(years)vs(II) playing one's role }\end{array}$ & $-0,01$ & 0,9663 \\
\hline $\begin{array}{l}\text { Wiek (lata) vs (I) funkcje emocjonalne/ } \\
\text { Age(years)vs(I) emotional functions }\end{array}$ & $-0,06$ & 0,7345 \\
\hline $\begin{array}{l}\text { Wiek (lata) vs (II) funkcje emocjonalne/ } \\
\text { Age(years)vs(II) emotional functions }\end{array}$ & 0,00 & 0,9828 \\
\hline $\begin{array}{l}\text { Wiek (lata) vs (I) funkcje poznawcze/ } \\
\text { Age(years)vs(I) cognitive functions }\end{array}$ & $-0,02$ & 0,9165 \\
\hline $\begin{array}{l}\text { Wiek (lata) vs (II) funkcje poznawcze/ } \\
\text { Age(years)vs(II) cognitive functions }\end{array}$ & $-0,26$ & 0,1622 \\
\hline $\begin{array}{l}\text { Wiek (lata) vs (I) funkcje społeczne/ } \\
\text { Age(years)vs(I) social functions }\end{array}$ & $-0,09$ & 0,6397 \\
\hline $\begin{array}{l}\text { Wiek (lata) vs (II) funkcje społeczne/ } \\
\text { Age(years)vs(II) social functions }\end{array}$ & $-0,05$ & 0,7996 \\
\hline $\begin{array}{l}\text { Wiek (lata) vs (I) zmęczenie/ } \\
\text { Age(years)vs(I)fatigue }\end{array}$ & $-0,01$ & 0,9416 \\
\hline $\begin{array}{l}\text { Wiek (lata) vs (II) zmęczenie/ } \\
\text { Age(years)vs(II)fatigue }\end{array}$ & 0,08 & 0,6847 \\
\hline $\begin{array}{l}\text { Wiek (lata) vs (I) nudności/wymioty/ } \\
\text { Age(years)vs(I) nausea/vomiting }\end{array}$ & $-0,08$ & 0,6716 \\
\hline $\begin{array}{l}\text { Wiek (lata) vs (II) nudności/wymioty/ } \\
\text { Age(years)vs(II) nausea/vomiting }\end{array}$ & 0,00 & 0,9888 \\
\hline $\begin{array}{l}\text { Wiek (lata) vs (I) bóle/ } \\
\text { Age(years)vs(I) headaches }\end{array}$ & $-0,05$ & 0,7994 \\
\hline $\begin{array}{l}\text { Wiek (lata) vs (II) bóle/ } \\
\text { Age(years)vs(II) headaches }\end{array}$ & 0,04 & 0,8278 \\
\hline $\begin{array}{c}\text { Wiek (lata) vs (I) duszności/ } \\
\text { Age(years)vs(I) shortness of breath }\end{array}$ & $-0,11$ & 0,5644 \\
\hline $\begin{array}{c}\text { Wiek (lata) vs (II) duszności/ } \\
\text { Age(years)vs(II) shortness of breath }\end{array}$ & $-0,02$ & 0,8954 \\
\hline $\begin{array}{l}\text { Wiek (lata) vs (I) bezsenność/ } \\
\text { Age(years)vs(I)insomnia }\end{array}$ & $-0,04$ & 0,8418 \\
\hline
\end{tabular}

\begin{tabular}{|c|c|c|}
\hline $\begin{array}{l}\text { Wiek (lata) vs (II) bezsennośćl } \\
\text { Age(years)vs(II)insomnia }\end{array}$ & 0,08 & 0,6738 \\
\hline $\begin{array}{l}\text { Wiek (lata) vs (I) brak apetytu/ } \\
\text { Age(years)vs(I) lack of apetite }\end{array}$ & 0,13 & 0,4959 \\
\hline $\begin{array}{l}\text { Wiek (lata) vs (II) brak apetytu/ } \\
\text { Age(years)vs(II) lack of apetite }\end{array}$ & $-0,02$ & 0,9038 \\
\hline $\begin{array}{l}\text { Wiek (lata) vs (I) zaparcia/ } \\
\text { Age(years)vs(I) constipation }\end{array}$ & $-0,26$ & 0,1513 \\
\hline $\begin{array}{l}\text { Wiek (lata) vs (II) zaparcia/ } \\
\text { Age(years)vs(II) constipation }\end{array}$ & $-0,06$ & 0,7352 \\
\hline $\begin{array}{l}\text { Wiek (lata) vs (I) biegunka/ } \\
\text { Age(years)vs(I)diarrhoea }\end{array}$ & $-0,02$ & 0,9315 \\
\hline $\begin{array}{l}\text { Wiek (lata) vs (II) biegunka/ } \\
\text { Age(years)vs(II)diarrhoea }\end{array}$ & $-0,07$ & 0,6960 \\
\hline $\begin{array}{l}\text { Wiek (lata) vs (I) problemy finansowe/ } \\
\text { Age(years)vs(I) financial problems }\end{array}$ & 0,04 & 0,8142 \\
\hline $\begin{array}{l}\text { Wiek (lata) vs (II) problemy finansowe/ } \\
\text { Age(years)vs(II) financial problems }\end{array}$ & 0,04 & 0,8142 \\
\hline $\begin{array}{l}\text { Wiek (lata) vs (I) dziedzina fizyczna/ } \\
\text { Age(years)vs(I) physical discipline }\end{array}$ & $-0,01$ & 0,9547 \\
\hline $\begin{array}{l}\text { Wiek (lata) vs (II) dziedzina fizyczna/ } \\
\text { Age(years)vs(II) physical discipline }\end{array}$ & $-0,10$ & 0,6065 \\
\hline $\begin{array}{l}\text { Wiek (lata) vs (I) relacje społeczne/ } \\
\text { Age(years)vs(I) social relations }\end{array}$ & $-0,21$ & 0,2487 \\
\hline $\begin{array}{l}\text { Wiek (lata) vs (II) relacje społeczne/ } \\
\text { Age(years)vs(II) social relations }\end{array}$ & $-0,21$ & 0,2467 \\
\hline $\begin{array}{l}\text { Wiek (lata) vs (I) dziedzina psychologiczna/ } \\
\text { Age(years)vs(I) psychological discipline }\end{array}$ & $-0,13$ & 0,4897 \\
\hline $\begin{array}{l}\text { Wiek (lata) vs (II) dziedzina psychologiczna/ } \\
\text { Age(years)vs(II) psychological discipline }\end{array}$ & $-0,13$ & 0,5000 \\
\hline $\begin{array}{l}\text { Wiek (lata) vs (I) środowisko/ } \\
\text { Age(years)vs(I) environment }\end{array}$ & 0,19 & 0,3022 \\
\hline $\begin{array}{l}\text { Wiek (lata) vs (II) środowisko/ } \\
\text { Age(years)vs(II) environment }\end{array}$ & 0,17 & 0,3681 \\
\hline
\end{tabular}

Źródło: badania własne

Source: author's own materials

Nie ma również istotnych statystycznie korelacji pomiędzy jakością życia a czasem, jaki minął od operacji (dla osób wcześniej operowanych). Tu także zastosowano współczynnik korelacji rang Spearmana.

Tabela 10. Wyniki korelacji pomiaru pierwszego (I) i drugiego (II) z zastosowaniem testu Spearmana

Table 10. The correlation results of the first (I) and second (II) measurement using the Spearman test

\begin{tabular}{|c|c|c|}
\hline $\begin{array}{l}\text { Para zmiennych/ } \\
\text { Pair of variables }\end{array}$ & R Spearman & $\mathrm{p}$ \\
\hline $\begin{array}{l}\text { Czas od operacji vs (I) stan zdrowia i jakość życia/ } \\
\text { Time since surgery vs (I) health and quality of life }\end{array}$ & 0,18 & 0,3570 \\
\hline $\begin{array}{l}\text { Czas od operacji vs (II) Stan zdrowia i jakość życia/ } \\
\text { Time since surgery vs (II) health and quality of life }\end{array}$ & 0,12 & 0,5316 \\
\hline $\begin{array}{l}\text { Czas od operacji vs (I) funkcje fizyczne/ } \\
\text { Time since surgery vs (I) physical functions }\end{array}$ & 0,00 & 0,9972 \\
\hline $\begin{array}{l}\text { Czas od operacji vs (II) funkcje fizyczne/ } \\
\text { Time since surgery vs (II) physical functions }\end{array}$ & $-0,02$ & 0,9094 \\
\hline $\begin{array}{l}\text { Czas od operacji vs (I) pełnienie swej roli/ } \\
\text { Time since surgery vs (I) act as }\end{array}$ & 0,10 & 0,5998 \\
\hline $\begin{array}{l}\text { Czas od operacji vs (II) pełnienie swej roli/ } \\
\text { Time since surgery vs (II) act as }\end{array}$ & 0,12 & 0,5386 \\
\hline $\begin{array}{l}\text { Czas od operacji vs (l) funkcje emocjonalne/ } \\
\text { Time since surgery vs (I) emotional functions }\end{array}$ & $-0,17$ & 0,3959 \\
\hline $\begin{array}{l}\text { Czas od operacji vs (II) funkcje emocjonalne/ } \\
\text { Time since surgery vs (II) emotional functions }\end{array}$ & $-0,09$ & 0,6365 \\
\hline
\end{tabular}


Czas od operacji vs (I) funkcje poznawcze/ Time since surgery vs (I) cognition functions Czas od operacji vs (II) funkcje poznawcze/ Time since surgery vs (II) cognition functions Czas od operacji vs (I) funkcje społeczne/ Time since surgery vs (I) social functions Czas od operacji vs (II) funkcje społeczne/ Time since surgery vs (II) social functions Czas od operacji vs (I) zmęczenie/ Time since surgery vs (I) fatigue Czas od operacji vs (II) zmęczenie/ Time since surgery vs (II) fatigue Czas od operacji vs (I) nudności/wymioty/ Time since surgery vs (I) nausea/vomiting Czas od operacji vs (II) nudności/wymioty/ Time since surgery vs (II) nausea/vomiting Czas od operacji vs (I) bóle/ Time since surgery vs (I) headaches Czas od operacji vs (II) bólel Time since surgery vs (II) headaches Czas od operacji vs (I) duszności/

Time since surgery vs (I) shortness of breath Czas od operacji vs (II) duszności/

Time since surgery vs (II) shortness of breath Czas od operacji vs (I) bezsenność/ Time since surgery vs (I)insomnia

Czas od operacji vs (II) bezsenność/ Time since surgery vs (II)insomnia

Czas od operacji vs (I) brak apetytu/ Time since surgery vs (I) lack of apetite

Czas od operacji vs (II) brak apetytu/

Time since surgery vs (II) lack of apetite Czas od operacji vs (I) zaparcia/ Time since surgery vs (I) constipation Czas od operacji vs (II) zaparcia/ Time since surgery vs (II) constipation Czas od operacji vs (I) biegunka/ Time since surgery vs (I) diarrhoea Czas od operacji vs (II) biegunka/ Time since surgery vs (II) diarrhoea

Czas od operacji vs (I) problemy finansowe/ Time since surgery vs (I) financial problems Czas od operacji vs (II) problemy finansowe/ Time since surgery vs (II) financial problems Czas od operacji vs (I) dziedzina psychologiczna/ Time since surgery vs (I) psychological discipline Czas od operacji vs (II) dziedzina psychologiczna/ Time since surgery vs (II) psychological discipline Czas od operacji vs (I) relacje społeczne/ Time since surgery vs (I) social relations Czas od operacji vs (II) relacje społeczne/ Time since surgery vs (II) social relations Czas od operacji vs (I) środowisko/ Time since surgery vs (I) environment Czas od operacji vs (II) środowisko/ Time since surgery vs (II) environment Czas od operacji vs (I) dziedzina fizyczna/ Time since surgery vs (I) physical discipline Czas od operacji vs (II) dziedzina fizyczna/ Time since surgery vs (II) physical discipline

$-0,09 \quad 0,6434$

$0,16 \quad 0,4120$

$0,04 \quad 0,8254$

$-0,12 \quad 0,5377$

$-0,12 \quad 0,5377$

$-0,04 \quad 0,8572$

$0,19 \quad 0,3342$

$0,42 \quad 0,0246$

$0,37 \quad 0,0562$

$0,42 \quad 0,0261$

$0,39 \quad 0,0394$

$-0,04 \quad 0,8572$

$-0,10 \quad 0,6020$

Źródło: badania własne

Source: author's own materials

\section{Dyskusja}

Podjęty temat badań nad jakością życia chorych po termoablacji przezskórnej wątroby stanowił duże wyzwanie. Zagadnienie odnoszące się do pacjentów, u których zastosowano metodę leczenia termoablacyjnego, jest nowym i wcześniej nieujętym w żadnych badaniach lekarskich ani pielęgniarskich, stąd też wynika brak porównania wyników badań własnych z wynikami innych badaczy. Codzienna praca z chorymi, u których przeprowadza się zabieg ablacji wątroby, ciekawość dotycząca stanu ich zdrowia czy jakości życia skłoniły autorów do podjęcia się przeprowadzenia badań w tym kierunku.

Zgromadzenie dostatecznej liczby chorych do badania nie było łatwym zadaniem. Warunki wykonania zabiegu u pacjenta, jakie stawiane są przez jednostkę leczniczą, są bardzo rygorystyczne. Nie każda osoba może być zakwalifikowana do zabiegu, np. ze względu na stan zdrowia, jakim jest rozległy rozsiew nowotworowy, choroby współtowarzyszące, tj. układu oddechowego, a także wiek pacjenta czy niekorzystne umiejscowienie guza w obrębie narządu.

W przeprowadzonych badaniach uczestniczyło 31 pacjentów, w tym 17 kobiet i 14 mężczyzn. Każdy z ankietowanych był przed zabiegiem termoablacji przezskórnej wątroby. Wiek pacjentów klasyfikował się w granicach od 26. do powyżej 60. roku życia. Najliczniejszą grupę badanych stanowili chorzy powyżej 60. roku życia, bo aż 19 osób. Wysoka liczebność pacjentów w zaawansowanym wieku zakwalifikowanych do zabiegu świadczy o większej częstotliwości zapadalności na różnego rodzaju choroby wraz z wiekiem. U osób poniżej 60. roku życia częstotliwość ta jest znacznie mniejsza. Warto dodać, że do zabiegu termoablacji przezskórnej wątroby zakwalifikowało się więcej kobiet niż mężczyzn, co może sugerować wyższą podatność płci żeńskiej na choroby nowotworowe.

Wpływ wykształcenia nie nasuwa w badaniach żadnych konkretnych wniosków, mimo że osoby z wykształceniem zawodowym i średnim stanowiły najwyższy procent. Poziom wykształcenia nie wywiera większego wpływu na podatność na zachorowanie, jednakże na stopień porozumienia się z badanym czy prawidłową analizę pytań z kwestionariuszy badawczych - tak. Dokładniejszych i bardziej zrozumiałych odpowiedzi udzielały osoby z wykształceniem średnim i wyższym niż z zawodowym czy podstawowym.

Dość ciekawe wnioski nasuwają się z informacji odnośnie miejsca zamieszkania badanych. Najliczniejszą grupe zakwalifikowanych do zabiegu stanowiły osoby pochodzące z miast powyżej 25 tys. mieszkańców, co może świadczyć o większej dostępności do informacji odnośnie najnowszych metod leczenia, wśród których jest termoablacja.

Aktualnie deklarowany przez chorych status zawodowy również potwierdza teorię wieku. Najliczniejszą grupę badanych stanowili emeryci i renciści. Aktyw- 
nych zawodowo, którym choroba nie umożliwia dalszej działalności zawodowej, było 22,6\%. Najczęściej byli to pacjenci z rozpoznanym nowotworem wątroby lub pacjenci, u których od zabiegu operacyjnego minął ponad rok, lub pacjenci, którzy nie byli poddani leczeniu operacyjnemu.

Stan cywilny chorych także nie ma wpływu na ich zachorowanie, jednakże odnośnie jakości życia czy wsparcia w chorobie ma duże znaczenie. Osoby pozostające w związkach znacznie wyżej określały jakość swojego życia, zadowolenie z samego siebie czy relacji międzyludzkich. Zauważono również bardziej pozytywne nastawienie na proponowaną formę leczenia i chęć walki o własne zdrowie. Najliczniejszą grupę pacjentów stanowiły właśnie osoby będące w związku małżeńskim.

Bardzo ważną informację stanowi podstawowe rozpoznanie jednostki chorobowej pacjenta. Najwięcej, bo aż 45,2\%, stanowiła grupa chorych, u których zdiagnozowano nowotwór jelita grubego. Potwierdza to założenie, że u osób chorujących na nowotwór jelita grubego najczęściej dochodzi do przerzutów w obrębie narządu wątroby, przez co do leczenia termoablacyjnego kwalifikowanych jest najwięcej pacjentów z tym rozpoznaniem. Równie liczną grupę stanowili badani z nowotworem wątroby - 35,5\%, u których w standardowym postępowaniu stosuje się, w celu uniknięcia leczenia rozległym zabiegiem operacyjnym, metodę przezskórnej termoablacji. Także chorych z nowotworem piersi, odbytu, żołądka czy guzem ogona trzustki kwalifikowano do zabiegu ablacji. Warto dodać, że najmłodszą grupe pacjentów stanowiły kobiety z postawionym rozpoznaniem nowotworu piersi. Najczęstszym rozpoznaniem podstawowej jednostki chorobowej był nowotwór jelita grubego, co potwierdza, że schorzenie to częściej niż inne daje zmiany ogniskowe w obrębie wątroby, a to wiąże się z koniecznością wykonania zabiegu termoablacji po kwalifikacji do tego zabiegu.

Odnosząc się do stosowanych metod leczenia, jakie deklarowali w kwestionariuszu badani, na równi w najwyższym procencie są chemioterapia oraz leczenie operacyjne. Obie metody terapeutyczne przeważnie zalecane są w leczeniu pacjentów onkologicznych, przez co wynik nie jest zaskakujący. Dodatkowo wymienione leczenie radioterapeutyczne zdeklarowało $29 \%$ pacjentów. Wnioskując, standardowym postępowaniem jest leczenie operacyjne z chemioterapią przed wykonaniem zabiegu termoablacji przezskórnej wątroby.

$\mathrm{U}$ większości ankietowanych chorych leczenie termoablacyjne poprzedzone było leczeniem operacyjnym. Tylko 9,7\% nie zostało poddanych żadnemu zabiegowi. Największy procent stanowiła grupa chorych w przedziale od roku do 2 lat po operacji, u których zdiagnozowano zmiany ogniskowe w obrębie narządu wątroby. Na tej podstawie można wysnuć dwa podstawowe wnioski: pierwszy - potwierdzający słuszność regularnych oraz jak najszybciej wdrożonych badań kontrolnych w kierunku przerzutów do wątroby, drugi - jak szybko u pacjenta chorującego onkologicznie dochodzi do dalszych powikłań i rozsiewów nowotworowych mimo stosowanego leczenia.

Powyżej przedstawione fakty stanowią bazę podstawowych informacji na temat badanej grupy pacjentów.

W niniejszej pracy badawczej skupiono się na aspekcie jakości życia chorych po przezskórnej termoablacji wątroby. By porównać i wyciągnąć wnioski odnośnie standardu życia badanych, zdecydowano się użyć dostępnych kwestionariuszy oceniających jakość życia. Badania prowadzono na jednej stałej grupie 31 osób zakwalifikowanych do zabiegu ablacji. Ankieta została przeprowadzona dzień przed termoablacją oraz 2 tygodnie po zabiegu. Wyznaczony czas 2 tygodni nie jest przypadkowy, gdyż wspierając się konsultacją od specjalisty w zakresie wątroby i jej leczenia, stwierdzono, że termin ten stanowi czas minimalny, po jakim można sprawdzić zmiany w jakości życia chorych.

Według pierwszego z wybranych kwestionariuszy, czyli EORTC QLQ-C30, oceniono pacjentów w podziale skal funkcjonalnych i objawowych narzędzia badawczego.

W funkcjonalnych aspektach największe zmiany zauważono w dziedzinie stanu zdrowia i jakości życia oraz stanu emocjonalnego pacjentów. Oba aspekty bardzo mocno odnoszą się do zagadnienia jakości życia. Dziedzina stanu zdrowia przed zabiegiem wynosiła średnio 46,2\%, a 2 tygodnie po wzrosła aż do 55,6\%. Różnice można określić jako dużą, mając na uwadze niedługi czas, jaki upłynął po ablacji. Wnioskując, jakość życia i stan zdrowia to aspekt, który uległ znacznej poprawie. Odnosząc się do dziedziny emocjonalnej, również zauważono tendencję pozytywnie wzrostową. Przed zabiegiem średnią określano na 49,5\%, a po 2-tygodniowej przerwie - na 75,3\%. Aspekt emocjonalny jest tutaj o tyle ważny, że pozytywne nastawienie emocjonalne na wiadomości o ponownej chorobie i kontynuowaniu terapii daje lepsze wyniki w leczeniu, chęć do dalszej walki o własne zdrowie oraz nadzieję na lepszą jakość życia i stan zdrowia. Pozostałe czynniki funkcjonalne takie jak: funkcje fizyczne, pełnienie swej roli, funkcje poznawcze oraz funkcje społeczne także uległy poprawie, jednak w mniejszym procencie. Podsumowując, zastosowany test Wilcoxona wykazał istotne statystycznie różnice przed zabiegiem i po zabiegu w obu głównych aspektach skali funkcjonalnej.

Analizując punkty skali objawowej, można zauważyć istotne statystycznie różnice w: odczuwanym zmęczeniu, które z 41,6\% spadło do 32,3\%, bezsenności 
- z 46,2\% do 35,5\% oraz braku apetytu - z 22,6\% do $11,8 \%$. Każdy z trzech wymienionych czynników według testu Wilcoxona potwierdza negatywny wpływ stresu i niepewności przed zabiegiem na wybrane aspekty życia chorego; po przeprowadzonej termoablacji dane objawy są mniej odczuwalne w sposób negatywny niż wcześniej. Pozostałe objawy takie jak: nudności/wymioty, bóle, duszności, zaparcia czy biegunka również uległy zmniejszeniu, jednak w mniejszym stopniu. Bez zmian pozostał aspekt problemów finansowych.

Na podstawie skali WHOQOL-BREF i korzystając z testu Wilcoxona, istotne statystycznie różnice wykazano w dziedzinie fizycznej oraz psychologicznej badanych pacjentów. W aspekcie fizycznym nastąpiła znaczna poprawa z 12,4\% do 13,1\% średniej. Natomiast w aspekcie psychologicznym z 12,8\% aż do 14\%. Można śmiało wywnioskować, że mimo upływu 2 tygodni od zabiegu u chorych wystąpiła znaczna poprawa jakości życia w sferze fizycznej oraz psychologicznej. Do mniej istotnej, ale również pozytywnej poprawy doszło w pozostałych dziedzinach życia, takich jak relacje społeczne oraz środowisko.

Oba użyte do badania kwestionariusze wykazały poprawę w jakości życia chorych ze zmianami ogniskowymi w obrębie wątroby po zastosowaniu metody leczenia, jaką jest termoablacja przezskórna.

Podsumowując, można dodać, że porównując jakość życia u kobiet i mężczyzn, różnice ze względu na płeć nie wystąpiły i nie są istotne statystycznie. Podobne wyniki uzyskano również, porównując wiek badanych pacjentów czy czas, jaki minął od operacji. Żaden z wymienionych aspektów nie wpływał na jakość życia chorych. Zmienne płci i wieku nie są czynnikami istotnymi statystycznie.

\section{Wnioski}

1. Według skali EORTC-C30 oraz WHOQOL-BREF jakość życia pacjentów po 2 tygodniach od zabiegu uległa znacznej poprawie.

2. Zmiennymi, które nie mają wpływu na jakość życia pacjentów, są płeć, wiek oraz czas, jaki minął od operacji.

3. Przeprowadzone badania należy traktować jako wstępne i rozszerzyć o większą liczbę badanych, zakres czasowy po zabiegu (2 tygodnie/3 miesiące/6 miesięcy/rok), a także liczbę wykonanych termoablacji u danego pacjenta.

4. Przeprowadzone badania stanowią nowe źródło wiedzy ukazujące pozytywny wpływ nowej metody leczenia, jaką jest termoablacja przezskórna wątroby. Metoda termoablacji potwierdza zbliżony stopień skuteczności leczenia w porównaniu do klasycznego zabiegu operacyjnego, ze znacznie mniejszym odczuciem cierpienia somatycznego i psychicznego pacjenta.

\section{Piśmiennictwo}

1. D’Angelica M, Fong Y. Wątroba. W: Townsend CM et al. (red.). Sabiston. Chirurgia. T. 4. Wrocław: Elsevier Urban \& Partner; 2013. 358-411.

2. Zadrożny D, Śledziński Z, Studniarek M. Wczesne wyniki leczenia nowotworów pierwotnych i wtórnych wątroby metodą przezskórnej termoablacji. Pol Prz Chir. 2008; 80, 8: 730-742.

3. Stańczyk M, Zegadło A, Zwierowicz T, Żak D, Bogusławska R, Maruszyński M. Mikrofalowa ablacja guzów wątroby jako nowe narzędzie w mało inwazyjnej chirurgii wątroby. Pol Merk Lek. 2009; 26, 155: 545-549.

4. Locker GY, Hamilton S, Harris J. Update of Recommendations for the Use of Tumor Markers in Gastrointestinal Cancer. J Clin Oncol. 2006; 33: 5313-5327.

5. Krawczyk M, Patkowski W. Chirurgia wątroby. Med Prakt Chir. 2011; 2: 49-55.

6. Padma S, Martinie JB, lannitti DA. Ablacja guzów wątrobymetody przezskórne i operacyjne. Med Prakt - Chirurgia. 2010; 5, 93: 41-64.

7. Kulig J, Nowak W, Kołodziejczyk P, Kłęk S, Sierżęga M, Gach T. Przezskórna termoablacja nowotworów złośliwych wątroby. Ultrasonografia. 2007; 29: 23-29.

8. Pyra A, Pyda P, Drews M. Termoablacja ogniskowych zmian nowotworowych w wątrobie - opis metody. Now Lek. 2007; 76, 3: 256-260.

9. Biernacki M, Tenderenda M, Michalak M. Wartość termoablacji w leczeniu pierwotnych i przerzutowych guzów nowotworowych wątroby. Rocz Med. 2007; 14, 1: 29-33.

10. Rubinsky B, Onik G, Mikus P. Irreversible electroporation: a new ablation modality - clinical implications. Technol Cancer Res Treat. 2007; 6, 1: 37-48.

11. Stelcer B. Jakość życia i integracja psychiczna. W: Wołowicka $L$ (red.). Jakość życia w naukach medycznych QOL in medical sciences. Poznań: Dział Wydawnictw Uczelnianych AM im. Karola Marcinkowskiego; 2001. 117-127.

12. Leppert W, Majkowicz M. Validation of the Polish version of the European Organization for Research and Treatment of Cancer Quality of Life Questionnaire - Core 15 - Palliative Care (EORTC QLQ-C15-PAL) in patients with advanced cancer. Palliat Med. 2013; 27: 470-477.

13. Stychno E, Kulczycka K. Problemy badawcze w badaniach jakościowych w pielęgniarstwie. Piel XXI w. 2009, 1/2, 26/27: 121-123.

14. Sierakowska M, Krajewska-Kułak E, Lewko J. Problemy jakości życia w chorobach przewlekłych. W: Krajewska-Kułak E, Sierakowska M, Lewko J, Łukaszuk C (red.). Pacjent podmiotem troski zespołu terapeutycznego. T. 1. Białystok: Wydział Pielęgniarstwa i Ochrony Zdrowia AM w Białymstoku; 2005. 35.

Artykuł przyjęty do redakcji: 24.10.2016

Artykuł przyjęty do publikacji: 15.12.2016

Źródło finansowania: Praca nie jest finansowana z żadnego źródła. Konflikt interesów: Autorzy deklarują brak konfliktu interesów.

Adres do korespondencji:

Beata Bożek-Bezler

ul. Cypriana Norwida 17/7

60-867 Poznań

tel.: 618612261

e-mail: beata.db3@gmail.com

Zakład Praktyki Pielęgniarskiej, Katedra Pielęgniarstwa

Uniwersytet Medyczny im. Karola Marcinkowskiego w Poznaniu 